\title{
PENGARUH PERSONAL POWER DAN LEGITIMATE POWER TERHADAP KINERJA PEGAWAI
}

\author{
Hasanuddin ${ }^{1}$, Andi Ismawaty ${ }^{2}$, Muhammad Syarkawi ${ }^{3}$ ) \\ ${ }_{1}^{1}$ Jurusan Ilmu Administrasi Negara, STISIP Bina Generasi Polewali \\ Email: : hasanuddin@stisipbiges.ac.id \\ ${ }^{2}$ Jurusan Ilmu Administrasi Negara, STISIP Bina Generasi Polwwali \\ Email: andiismawaty@stisipbiges.ac.id \\ ${ }^{3}$ Mahasiswa Jurusan Ilmu Administrasi Negara, STISIP Bina Generasi Polewali
}

\begin{abstract}
Leadership is a way for a leader to direct and manage all elements in the group and his organization to achieve goals so that this leadership is expected to improve the performance of its employees or group members. This study aims to determine the effect of leadership in the Sidodadi Village Office, Wonomulyo Subdistrict, Polewali Mandar Regency, with its dimensions that significantly influence employee performance, namely legitimate power (formal power) and personal power (self ability). This research uses a quantitative approach which results are presented descriptively. For the purposes of quantitative analysis in this study using a Likert Scale, the scale of measurement in Ordinal to determine the respondent's answers in the form of statements that are Strongly Agree, Agree, Between Agree Disagree, Disagree and Strongly Disagree with the answers to each item has a gradation from positive with a score (5-1) to the score for the opposite. While the data processing techniques in this study, using linear regression statistical testing. The results showed that the performance of employees will be influenced by how much leadership is given by the organization so that the increase in the ability of leaders to encourage employee productivity must still be improved.
\end{abstract}

Keyword: Legitimate Power, Personal Power and Performance

\begin{abstract}
ABSTRAK
Kepemimpinan merupakan cara dari seorang pemimpin dalam mengarahkan dan mengatur semua unsur-unsur didalam kelompok dan organisasinya untuk mencapai tujuan sehingga diharapkan kepemimpinan ini dapat meningkatkan kinerja pegawainya atau anggota kelompoknya. Penelitian ini bertujuan untuk mengetahui pengaruh kepemimpinan di Kantor Kelurahan Sidodadi Kecamatan Wonomulyo Kabupaten Polewali Mandar dengan dimensi-dimensinya yang secara signifikan berpengaruh terhadap kinerja pegawai yakni legitimate power (kekuasaan formal) dan personal power (kemampuan diri). Penelitian ini menggunakan metode pendekatan kuantitatif yang hasilnya dikemukakan secara deskriptif. Untuk keperluan analisis kuantitatif dalam penelitian ini menggunakan Skala Likert, yang skala pengukurannya pada Ordinal untuk menentukan jawaban responden yang berupa pernyataan yaitu Sangat Setuju (SS), Setuju (SS), Antara Setuju Tidak Setuju (ASTS), Tidak Setuju(TS) dan Sangat Tidak Setuju (STS) dengan jawaban setiap item mempunyai gradasi dari positif dengan skor nilai (5-1) sampai dengan skor nilai untuk sebaliknya. Sedangkan teknik pengolahan data dalam penelitian ini, menggunakan pengujian statistik regresi linier. Hasil Penelitian menunjukkan bahwa kinerja pegawai akan dipengaruhi oleh berapa besar kepemimpinan
\end{abstract}


yang diberikan oleh organisasi sehingga peningkatan kemampuan pemimpin dalam mendorong produktivitas pegawainya masih harus ditingkatkan.

Kata Kunci : Legitimate power, Personal power, dan Kinerja pegawai

\section{PENDAHULUAN}

Kepemimpinan memegang peranan yang sangat penting bagi keberhasilan suatu organisasi. Dalam konteks ini kepemimpinan selain diperlukan untuk mempengaruhi, memotivasi, mengarahkan dan berkomunikasi juga diperlukan dalam menggerakkan bawahan untuk mencapai tujuan organisasi agar dapat tercapai seperti apa yang diharapkan.

Kepemimpinan merupakan salah satu faktor dalam peningkatan kinerja pegawai karena pada dasarnya kepemimpinan adalah tingkah laku seorang pemimpin dalam mendorong, mempengaruhi semangat kerja yang baik kepada bawahan.

Kepemimpinan yang efektif harus memberikan pengarahan terhadap usahausaha semua pekerja dalam mencapai tujuan organisasi. Tanpa kepemimpinan, hubungan antara tujuan perseorangan dan tujuan organisasi mungkin menjadi tidak searah \{Formatting Citation\}. Namun demikian dalam penerapannya, kepemimpinan mengandung banyak tantangan, baik tantangan yang timbul dari pimpinan sendiri, dari pengikut atau bawahan, maupun dari situasi dimana proses tersebut berlangsung. Sehingga untuk mengantisipasinya seorang pemimpin perlu menerapkan kepemimpinan (leadership style) yang tepat sesuai dengan situasi dan kondisi yang ada. Oleh karena itu seorang pemimpin dituntut untuk bersifat fleksibel agar dapat menyesuaikan dirinya dengan lingkungan organisasi. Hal ini dirasakan perlu karena menimbulkan semangat kerja bawahannya, sehingga dapat memacu kinerja pegawai yang optimal.

Kepemimpinan merupakan suatu proses mengarahkan dan mempengaruhi aktivitas yang berkaitan dengan pekerjaan dan anggota kelompok.

Kinerja merupakan kata yang digunakan untuk menjelaskan hasil kerka seseorang, kelompok ataupun organisasi sesuai dengan tugas, kewenangan yang dimiliki untuk mencapai tujuan organisasi. Padanan istilah kinerja diidentikkan dengan istilah performance.

Kinerja suatu organisasi pun menjadi sangat penting dalam pencapaian tujuan organisasi,. Kinerja organisasi itu sendiri ditentukan oleh kinerja setiap individu dalam hal ini pegawai dalam menjalankan tugas dan pekerjaan. Apalagi dalam pemberian pelayanan bagi masyarakat. Pelayanan publik selalu dikaitkan dengan suatu kegiatan yang dilakukan oleh seseorang atau kelompok orang atau instansi tertentu untuk memberikan bantuan dan kemudahan kepada masyarakat dalam rangka mencapai tujuan tertentu (Nurdin, Indonesia, \& Makassar, 2019) Sehingga kinerja pegawai yang optimal sangatlah dibutuhkan.

Kinerja merupakan performance atau unjuk kerja. Kinerja dapat pula diartikan sebagai prestasi kerja atau pelaksanaan kerja atau hasil unjuk kerja. Sehingga kinerja dapat disimpulkan sebagai hasil yang dicapai seseorang menurut ukuran yang berlaku dalam kurun waktu tertentu berkenaan dengan pekerjaan serta perilaku dan tindakannya.Kinerja dapat dikukur dari beberapa indikator antara lain : kualitas kerja, kuantitas kerja, tanggung jawab, dan sikap. Kualitas, yaitu hasil kegiatan yang dilakukan mendekati sempurna, dalam arti menyesuaikan beberapa cara ideal dari penampilan kegiatan dalam memenuhi tujuan 
yang diharapkan dari suatu kegiatan.(Rorimpandey, n.d.)

Didalam kepegawaian, kinerja merupakan suatu sistem kepegawaian dimana pengangkatan seseorang untuk menduduki jabatan atau naik pangkat didasarkan pada kecakapan dan prestasi yang dicapai oleh pegawai yang diangkat. Kinerja seseorang dalam menggerakkan roda organisasi kearah tujuan yang ditentukan tergantung seberapa jauh tingkat pengetahuan, tingkat ketrampilan dan tingkat sikap yang dimiliki masing-masing anggota organisasi. Jadi tercapai atau tidaknya tujuan organisasi terutama ditentukan oleh kualitas dan kuantitas dari orang yang bekerja pada organisasi itu sendiri.

Sikap pemimpin yang tegas dan proaktif yang diberikan kepada pegawai di kantor Kelurahan Sidodadi Kecamatan Wonomulyo Kabupaten Polewali Mandar dalam meningkatkan kinerja pegawai terutama dalam memberikan pelayanan kepada masyarakat secara maksimal serta kedisiplinan dalam mengerjakan tugasnya dengan waktu yang relatif cepat dan berkualitas.

Studi tentang pengaruh kepemimpinan terhadap kinerja pegawai telah banyak dilakukan. Monce (2016) dalam penelitiannya menunjukkan bahwa kepemimpinan dapat mempengaruhi kesuksesan pegawai. Dan terdapat satu ciri khas yang mendominasi pada penerapan kepemimpinan dalam menciptakan kondisi kerja yang harmonis dan nyaman serta selalu mengedepankan tugas yang diberikan sehingga pegawai bisa lebih bertanggung jawab terhadap tugas yang diberikan.

Hasil penelitian Arie Puspita dkk (2016) juga menunjukkan bahwa kepemimpinan berpengaruh secara positif dan signifikan terhadap kinerja pegawai. tinggi rendahnya variabel kepemimpinan, yang meliputi inspirational motivation, integrity, innovation, impression management, individual consideration, intellectual stimulation, trust, dan motivasi kerja dalam hal ini yang meliputi dimensi sosial, dimensi mental, dan dimensi fisik, akan berpengaruh secara signifikan positif terhadap kinerja karyawan(Puspita, 2016). Bahwa kepemimpinan, dan motivasi kerja karyawan, akan berpengaruh terhadap tinggi rendahnya atau baik buruknya kinerja karyawan.

Teori yang dikemukakan oleh French dan Rave menyatakan bahwa kepemimpinan bersumber pada kekuasaan dalam satu kelompok atau organisasi. seseorang atau orang-orang yang memiliki akses terhadap sumber kekuasaan dalam suatu kelompok atau organisasi tertentu akan mengendalikan atau memimpin kelompok atau organisasi itu (Raven, 2014). Disamping itu keberhasilan seorang pemimpin dalam melaksanakan fungsinya tidak hanya ditentukan oleh salah satu aspek semata-mata, melainkan antara sifat, perilaku, dan kekuasaan serta pengaruh saling menentukan sesuai dengan situasi yang mendukungnya. Kekuasaan dan pengaruh mempunyai peranan sebagai daya dorong bagi setiap pemimpin dalam mempengaruhi, menggerakkan, dan mengubah perilaku yang dipimpinnya ke arah pencapaian tujuan organisasi.

Konsepsi mengenai kepemimpinan tidak bisa dilepaskan dari kemampuan, kewibawaan dan kekuasaan. Kekuasaan merupakan kapasitas untuk mempengaruhi secara unilateral sikap dan perilaku orang ke arah yang diinginkan (A.Yukl, 2013). Dalam konteks ini kekuasaan dimaknai sebagai kemampuan dimana kemampuan merupakan sebagai salah satu dimensi kepemimpinan seperti kekuasaan formal (legitimate power) dan kemampuan diri (personal power).

Kekuasaan formal (legitimate power) berasal dari posisi resmi yang dijabat oleh seseorang, baik itu dalam suatu organisasi, birokrasi ataupun pemerintahan. Kekuasaan sah adalah kekuasaan yang diperoleh dari konsekuensi hirarki dalam organisasi. Seseorang yang menduduki posisi tertentu dalam organisasi memiliki hak dan wewenang untuk memberikan perintah dan instruksi dan mereka sebagai bawahan 
ataupun anggota tim berkewajiban untuk mengikuti instruksi atau perintah tersebut. Indokatornya adalah a) kemampuan merencanakan pekerjaan; b) kemampuan megorganisasikan pekerjaan; c) kemampuan menggerakkan sumber daya manusia serta d) kemampuan mengawasi dan mengevaluasi pekerjaan. Sedangkan indikator kemampuan diri (personal power) adalah a) kemampuan komunikasi; b) kemampuan berempati; c) kemampuan memberikan contoh; d) kemampuan memberikan pemahaman pekerjaan. Sehingga Yang membedakan penelitian ini dengan penelitian terdahulu adalah dalam penelitian ini ingin menganalisis kondisi kinerja pegawai berdasarkan pengaruh kepemimpinan di kantor Kelurahan Sidodadi Kecamatan Wonomulyo Kabupaten Polewali Mandar. Dalam hal ini pengaruh kepemimpinan ditinjau dari segi personal power dan legitimate power.

Berbagai permasalahan yang ditemukan dalam penelitian ini antara lain : a) Rendahnya disiplin kerja, contohnya: masih terdapat pegawai yang kurang taat terhadap program organisasi, seperti: tidak hadirnya pegawai dalam upacara, dalam pelaksanaan program kerja kurang memperhatikan jadwal kegiatan; b) kurang pedulinya pegawai terhadap lingkungan kerja, contohnya: masih lemahnya tingkat kerjasama diantara pegawai dalam; c) kurangnya tanggung jawab, contoh pada Seksi Ekonomi dan Pembangunan belum sepenuhnya mampu mengimplementasikan pendataan keluarga miskin untuk diselaraskan dengan data di desa; d) lemahnya inisiatif pegawai, contohnya, masih terdapat pegawai yang bekerja hanya dengan menunggu perintah atasan saja.

\section{METODE PENELITIAN}

Penelitian ini dilaksanakan pada Kantor Kelurahan Sidodadi Kecamatan Wonomulyo Kabupaten Polewali Mandar. Pemilihan lokasi penelitian ini karena masuk dalam kategori kinerja pegawai yang masih rendah serta kepemimpinan yang belum efektif. Karena populasi krang dari 100 orang, maka seluruh pegawai di kantor Lurah Sidodadi sebanyak 23 orang dijadikan sampel. Variabel dalam penelitian ini adalah kepemimpinan (X) dan kinerja pegawai (Y). Adapun data penelitian ini merupakan data primer yang diperoleh secara langsung dari responden melalui angket dan kuesioner. Hasil uji seluruh instrument menunjukkan bahwa seluruh item dalam variable adalah valid dan reliable.

\section{HASIL PENELITIAN DAN PEMBAHASAN}

Pada hasil dan pembahasan ini yang akan dikaji adalah pengaruh legitimate power dan personal power Lurah terhadap kinerja pegawainya, dimana masing-masing indikator diuji menggunakan instrument angket yang kemudian diuji validitas dan reliabilitasnya.

HASIL

Hasil penelitian ini menunjukkan bahwa kepemimpinan di kantor Kelurahan Sidodadi Kecamatan Wonomulyo Kabupaten Polewali Mandar dari segi Legitimate power dalam kemampuan merencanakan pekerjaan cukup baik dengan jumlah responden yang menyatakan setuju adalah 48\%. Kemampuan pimpinan dalam menggerakkan sumber daya manusia cukup baik, dimana jumlah responden yang menatakan setuju adalah 39\%. Begitupun kemampuan pimpinan dalam mengawasi dan mengevaluasi pekerjaan sudah baik dengan jumlah responden yang menyatakan sangat setuju sebesar 35\%. Begitu juga dengan kemampuan pimpinan dalam Namun pada kemampuan pimpinan dalam mengorganisasikan pekerjaan adalah masih rendah, hal ini terlihat dari responden yang menyatakan tidak setuju sebesar $39 \%$.

Jika dilihat dari segi personal power dalam hal kemampuan komunikasi pimpinan menunjukkan kondisi yang baik dengan persentasi responden yang setuju adalah sebesar 70\%, Begitu juga dengan kemampuan 
pimpinan dalam berempati itu cukup tinggi yakni $70 \%$ responden menyatakan setuju. Keteladan pimpinan dalam memberi contoh cukup baik, ditandai dengan responden yang menyatakan sangat setuju sebesar 52\%, sedangkan kemampuan pimpinan dalam memberikan pemahaman pekerjaan masih rendah dengan persentase responden yang tidak setuju adalah 48\%. Data lengkapnya dapat dilihat pada Tabel 1.

Tabel 1

Variabel Kepemimpinan (X)

\begin{tabular}{|c|c|c|c|c|c|}
\hline \multirow[b]{2}{*}{ Variabel $(X)$} & \multicolumn{5}{|c|}{$\mathrm{n}(\%)$} \\
\hline & SS & $\mathrm{S}$ & \begin{tabular}{|l} 
AST \\
S
\end{tabular} & TS & STS \\
\hline \multicolumn{6}{|c|}{ Legitimate Power (Kekuasaan Formal) } \\
\hline $\begin{array}{l}\text { Kemampuan } \\
\text { merencanakan } \\
\text { pekerjaan }\end{array}$ & $\begin{array}{c}6 \\
(26 \%)\end{array}$ & $\begin{array}{c}11 \\
(48 \%)\end{array}$ & $\begin{array}{c}6 \\
(26 \%)\end{array}$ & $\begin{array}{c}0 \\
(0 \%)\end{array}$ & $\begin{array}{c}0 \\
(0 \%)\end{array}$ \\
\hline $\begin{array}{l}\text { Kemampuan } \\
\text { megorganisasikan } \\
\text { pekerjaan }\end{array}$ & $\begin{array}{c}0 \\
(0 \%)\end{array}$ & $\begin{array}{c}2 \\
(9 \%)\end{array}$ & $\begin{array}{c}8 \\
(35 \%)\end{array}$ & $\begin{array}{c}9 \\
(39 \%)\end{array}$ & $\begin{array}{c}4 \\
(17 \%)\end{array}$ \\
\hline $\begin{array}{l}\text { Kemampuan } \\
\text { menggerakkan } \\
\text { SDM }\end{array}$ & $\begin{array}{c}3 \\
(13 \%)\end{array}$ & $\begin{array}{c}9 \\
(39 \%)\end{array}$ & $\begin{array}{c}9 \\
(39 \%)\end{array}$ & $\begin{array}{c}2 \\
(9 \%)\end{array}$ & $\begin{array}{c}0 \\
(0 \%)\end{array}$ \\
\hline $\begin{array}{l}\text { Kemampuan } \\
\text { mengawasi dan } \\
\text { mengevaluasi } \\
\text { pekerjaan }\end{array}$ & $\begin{array}{c}8 \\
(35 \%)\end{array}$ & $\begin{array}{c}8 \\
(35 \%)\end{array}$ & $\begin{array}{c}5 \\
(22 \%)\end{array}$ & $\begin{array}{c}2 \\
(9 \%)\end{array}$ & $\begin{array}{c}0 \\
(0 \%)\end{array}$ \\
\hline \multicolumn{6}{|c|}{ Personal Power (Kemampuan Diri) } \\
\hline $\begin{array}{l}\text { Kemampuan } \\
\text { komunikasi }\end{array}$ & $\begin{array}{c}3 \\
(13 \%)\end{array}$ & $\begin{array}{c}16 \\
(70 \%)\end{array}$ & $\begin{array}{c}4 \\
(17 \%)\end{array}$ & $\begin{array}{c}0 \\
(0 \%)\end{array}$ & $\begin{array}{c}0 \\
(0 \%)\end{array}$ \\
\hline $\begin{array}{l}\text { Kemampuan } \\
\text { berempati }\end{array}$ & $\begin{array}{c}5 \\
(22 \%)\end{array}$ & $\begin{array}{c}16 \\
(70 \%)\end{array}$ & $\begin{array}{c}2 \\
(9 \%)\end{array}$ & $\begin{array}{c}0 \\
(0 \%)\end{array}$ & $\begin{array}{c}0 \\
(0 \%)\end{array}$ \\
\hline $\begin{array}{l}\text { Kemampuan } \\
\text { memberikan } \\
\text { contoh }\end{array}$ & $\begin{array}{c}12 \\
(52 \%)\end{array}$ & $\begin{array}{c}11 \\
(48 \%)\end{array}$ & $\begin{array}{c}0 \\
(0 \%)\end{array}$ & $\begin{array}{c}0 \\
(0 \%)\end{array}$ & $\begin{array}{c}0 \\
(0 \%)\end{array}$ \\
\hline $\begin{array}{l}\text { Kemampuan } \\
\text { memberikan } \\
\text { pemahaman }\end{array}$ & $\begin{array}{c}0 \\
(0 \%)\end{array}$ & $\begin{array}{c}0 \\
(0 \%)\end{array}$ & $\begin{array}{c}0 \\
(0 \%)\end{array}$ & $\begin{array}{c}11 \\
(48 \%)\end{array}$ & $\begin{array}{c}12 \\
(52 \%)\end{array}$ \\
\hline
\end{tabular}

\begin{tabular}{|l|c|c|c|c|c|}
\hline pekerjaan & & & & & \\
\hline $\begin{array}{l}\text { Meningkatnya } \\
\text { Kinerja }\end{array}$ & 0 & 1 & 3 & 13 & 6 \\
& $(0 \%)$ & $(4 \%)$ & $(13 \%)$ & $(57 \%)$ & $(26 \%)$ \\
\hline
\end{tabular}

Berdasarkan Tabel 2 terlihat bahwa sebagian besar subjek penelitian menyatakan setuju bahwa sebagai pegawai senantiasa tanggap terhadap kritikan sebesar $48 \%$ dan menyatakan tidak setuju bahwa sebagai pegawai antusias dalam melakukan pekerjaan sebesar 61\%. Serta sebagian besar subjek penelitian menyatakan setuju bahwa sebagai pegawai senantiasa ada di tempat kerja pada jam kerja sebesar $78 \%$ dan menyatakan setuju bahwa sebagai pegawai senantiasa kreatif dalam menjalankan pekerjaannya sebesar $83 \%$.

Tabel 2 menunjukkan bahwa sebagian besar subjek penelitian menyatakan setuju bahwa sebagai pegawai senantiasa loyal peraturan atau kebijakan organisasi sebesar $57 \%$ dan menyatakan tidak setuju bahwa sebagai pegawai mempunyai komitmen yang kuat dalam melakukan pekerjaan di dalam organisasi sebesar 70\%. Serta sebagian besar subjek penelitian menyatakan setuju bahwa sebagai pegawai mempunyai rasa memiliki yang tinggi terhadap organisasi sebesar $70 \%$ dan menyatakan sangat setuju bahwa sebagai pegawai senantiasa patuh terhadap perintah yang diberikan atasan kepada para pegawai sebesar $48 \%$.

Sebagian besar subjek penelitian menyatakan setuju bahwa sebagai pegawai bisa melakukan kerjasama baik dengan atasan maupun dengan sesama bawahan sebesar $78 \%$ dan menyatakan tidak setuju dan sangat tidak setuju bahwa sebagai pegawai tidak bersedia untuk saling membantu dalam organisasi baik dengan sesama pegawai maupun dengan atasan masing-masing sebesar 35\%. Serta sebagian besar subjek penelitian menyatakan setuju bahwa sebagai pegawai mempunyai perasaan setia kawan terhadap sesama rekan kerja sebesar 48\% 
dan menyatakan sangat setuju bahwa suasana lingkungan pekerjaan sudah baik dan perlu dipertahankan sebesar 39\%. Selanjutnya subjek penelitian lebih banyak menyatakan agak setuju dan tidak setuju bahwa sebagai kesempatan promosi tidak terbuka bagi pegawai sebesar 39\% dan menyatakan sangat setuju dan setuju bahwa sebagai pegawai sudah merasakan keadilan di dalam pemberian Pelatihan sebesar 35\%.

Tabel 2

Variabel Kinerja Pegawai (Y)

\begin{tabular}{|c|c|c|c|c|c|}
\hline \multirow[b]{2}{*}{ Variabel (Y) } & \multicolumn{5}{|c|}{$\mathrm{n}(\%)$} \\
\hline & SS & $\mathrm{S}$ & ASTS & TS & STS \\
\hline \multicolumn{6}{|c|}{ Kedisiplinan } \\
\hline Tepat waktu & $\begin{array}{c}6 \\
\\
(26 \%)\end{array}$ & $\begin{array}{l}13 \\
(57 \\
\%)\end{array}$ & $\begin{array}{l}3 \\
(13 \%)\end{array}$ & $\begin{array}{l}1 \\
(4 \%)\end{array}$ & $\begin{array}{l}0 \\
(0 \%)\end{array}$ \\
\hline $\begin{array}{l}\text { Kepatuhan } \\
\text { Terhadap Aturan }\end{array}$ & $\begin{array}{l}0 \\
(0 \%)\end{array}$ & $\begin{array}{l}0 \\
(0 \%)\end{array}$ & $\begin{array}{l}7 \\
(30 \%)\end{array}$ & $\begin{array}{l}14 \\
(61 \\
\%)\end{array}$ & $\begin{array}{l}2 \\
(9 \%)\end{array}$ \\
\hline \multicolumn{6}{|l|}{ Kepedulian } \\
\hline $\begin{array}{l}\text { Empati terhadap } \\
\text { pegawai lain }\end{array}$ & $\begin{array}{l}3 \\
(13 \\
\%)\end{array}$ & $\begin{array}{l}18 \\
(78 \\
\%)\end{array}$ & $\begin{array}{l}2 \\
(9 \%)\end{array}$ & $\begin{array}{l}0 \\
(0 \% \\
)\end{array}$ & $\begin{array}{l}0 \\
(0 \% \\
)\end{array}$ \\
\hline $\begin{array}{l}\text { Rasa Memiliki } \\
\text { Terhadap } \\
\text { organisasi }\end{array}$ & $\begin{array}{l}2 \\
(9 \% \\
)\end{array}$ & $\begin{array}{l}19 \\
(83 \\
\%)\end{array}$ & $\begin{array}{l}1 \\
(4 \%)\end{array}$ & $\begin{array}{l}1 \\
(4 \% \\
)\end{array}$ & $\begin{array}{l}0 \\
(0 \% \\
)\end{array}$ \\
\hline \multicolumn{6}{|c|}{ Tanggung Jawab } \\
\hline $\begin{array}{l}\text { Penyelesaian } \\
\text { pekerjaan }\end{array}$ & $\begin{array}{l}1 \\
(4 \% \\
)\end{array}$ & $\begin{array}{l}13 \\
(57 \\
\%)\end{array}$ & $\begin{array}{l}8 \\
(35 \%)\end{array}$ & $\begin{array}{l}1 \\
(4 \% \\
)\end{array}$ & $\begin{array}{l}0 \\
(0 \%)\end{array}$ \\
\hline $\begin{array}{l}\text { Kesesuaian } \\
\text { dengan } \\
\text { perencanaan }\end{array}$ & $\begin{array}{l}0 \\
(0 \%)\end{array}$ & $\begin{array}{l}0 \\
(0 \%)\end{array}$ & $\begin{array}{l}3 \\
(13 \%)\end{array}$ & $\begin{array}{l}16 \\
(70 \\
\%)\end{array}$ & $\begin{array}{l}3 \\
(13 \\
\%)\end{array}$ \\
\hline Kualitas kerja & $\begin{array}{l}5 \\
(22 \\
\%)\end{array}$ & $\begin{array}{l}16 \\
(70 \\
\%)\end{array}$ & $\begin{array}{l}2 \\
(9 \%)\end{array}$ & $\begin{array}{l}0 \\
(0 \%)\end{array}$ & $\begin{array}{l}0 \\
(0 \%)\end{array}$ \\
\hline \multicolumn{6}{|c|}{ Kreativitas } \\
\hline Inisiatif & $\begin{array}{l}11 \\
(48 \\
\%)\end{array}$ & $\begin{array}{l}10 \\
(44 \\
\%)\end{array}$ & $\begin{array}{l}1 \\
(4 \%)\end{array}$ & $\begin{array}{l}1 \\
(4 \% \\
)\end{array}$ & $\begin{array}{l}0 \\
(0 \%)\end{array}$ \\
\hline
\end{tabular}

\begin{tabular}{|l|l|l|l|l|l|}
\hline Komunikasi & $\begin{array}{l}2 \\
(9 \%\end{array}$ & $\begin{array}{l}18 \\
(78\end{array}$ & 3 & 0 & 0 \\
& $(13 \%)$ & $(0 \%)$ & $(0 \%)$ \\
\hline
\end{tabular}

\section{Hubungan antara kepemimpinan dengan kinerja pegawai}

Tabel 3 menunjukkan bahwa dari 13 orang subjek penelitian memiliki Kinerja Pegawai baik pula sebanyak 12 orang (92\%) serta dari 10 orang subjek penelitian dengan tingkat Pelatihan kurang ternyata memiliki efektivitas organisasi dengan tingkat kurang pula sebanyak 6 orang $(60 \%)$ dan hasil analisis Chi Square Test pada derajat kepercayaan 95\% menunjukkan bahwa jika kepemimpinan dilaksanakan secara optimal, maka kinerja pegawai akan meningkat dengan nilai $\mathrm{p}=0,012$ (nilai $\mathrm{p} \leq 0,05$ ).

Tabel 3

Hubungan antara kepemimpinan dengan kinerja pegawai

\begin{tabular}{|c|c|c|c|c|}
\hline \multirow[b]{2}{*}{ Uraian } & \multicolumn{2}{|c|}{ Kinerja Pegawai } & \multirow[t]{2}{*}{ Total } & Nilai p \\
\hline & Baik & $\begin{array}{c}\text { Kuran } \\
\text { g }\end{array}$ & & \\
\hline Kepemimpin & & & & 0,012 \\
\hline an & & & & \\
\hline Baik & $\begin{array}{l}12 \\
(92, \%)\end{array}$ & $\begin{array}{c}1 \\
(8 \%)\end{array}$ & $\begin{array}{l}13 \\
(100 \%)\end{array}$ & \\
\hline Kurang & $\begin{array}{l}4 \\
(40 \%)\end{array}$ & $\begin{array}{c}6 \\
(60 \%)\end{array}$ & $\begin{array}{l}10 \\
(100 \%)\end{array}$ & \\
\hline Total & $\begin{array}{l}16 \\
(70 \%)\end{array}$ & $\begin{array}{c}7 \\
(30 \%)\end{array}$ & $\begin{array}{l}23 \\
(100 \%)\end{array}$ & \\
\hline
\end{tabular}

Pengaruh Kepemiminan terhadap kinerja pegawai

Tabel 4 menunjukkan bahwa hasil analisis Spearman Correlation Test pada derajat kepercayaan $95 \%$ menunjukkan bahwa terdapat pengaruh bermakna antara kepemimpinan terhadap kinerja pegawai dengan korelasi positif yang menunjukkan semakin optimal Kepemimpinan maka semakin tinggi Kinerja pegawai dengan nilai $\mathrm{p}<0,001$ dengan koefisien korelasi sebesar 0,75 yang menunjukkan kekuatan hubungan sangat kuat .

\section{Tabel 4}


Pengaruh kepemimpinan terhadap kinerja

\begin{tabular}{|l|c|c|}
\hline \multicolumn{1}{|c|}{ Uraian } & $\mathrm{r}_{\mathrm{sp}}$ & Nilai $\mathrm{p}$ \\
\hline $\begin{array}{l}\text { Pengaruh Kepemimpinan } \\
\text { terhadap Kinerja }\end{array}$ & 0,75 & $<0,001$ \\
\hline
\end{tabular}

\section{PEMBAHASAN}

Hasil penelitian ini menunjukkan responden menyatakan setuju terhadap penentuan yang diberikan sesuai dengan posisi yang ditempatinya, penyelesaian tugas tepat waktu yang dilakukan menunjukkan sistem Kepemimpinan berjalan baik, sistem Kepemimpinan berjalan dapat meningkatkan Kinerja Pegawai, berdasarkan prestasi dalam melaksanakan tugas, pemberian penghargaan berdasarkan keahlian dalam melaksanakan tugas, tingkat keahlian dalam melaksanakan tugas dapat mempengaruhi Kinerja Pegawai. Kinerja Pegawai akan meningkat, bila diberikan tanggung jawab tugas yang diberikan secara penuh, yang diimbangi dalam pemberian penghargaan.

Berdasarkan data tersebut dapatlah dikatakan bahwa bahwa sistem yang ada di dalam lingkungan organisasi memberikan sumbangsih terhadap peningkatan Kinerja Pegawai. Dalam melakukan pekerjaan jika sistem yang dibentuk didalam lingkungan organisasi yang kondusif dan memungkinkan untuk dilakukannya inovasi dan kreativitas. Berdasarkan data yang peneliti peroleh dari hasil tanggapan responden, diperoleh gambaran bahwa sistem sudah memberikan dukungan terhadap peningkatan Kinerja Pegawai walaupun masih perlu pembenahan dalam berbagai sisi misalnya dalam prosedur yang ada di dalam organisasi. Disamping itu kepemimpinan mencakup salah satunya adalah mekanisme yang dibangun di dalam organisasi. Sehingga mekanisme harus benarbenar ditentukan dan dijalankan oleh berbagai elemen organisasi sehingga tidak ada saling curiga dan saling menyalahkan karena semuanya telah jelas diatur dalam aturan organisasi.
Hasil penelitian ini juga menunjukkan bahwa kepemimpinan memberikan sumbangsih terhadap peningkatan Kinerja Pegawai. Kinerja Pegawai merupakan ketepatan tujuan, sasaran, waktu serta target yang dilakukan oleh organisasi karena untuk menghasilkan output tentunya ada proses yang dijalankan dan proses tersebut harus mengikuti alur yang ditetapkan oleh organisasi sehingga jika menepati proses yang dilakukan berdasarkan pada ketentuan yang ditetapkan oleh organisasi maka Kinerja Pegawai akan semakin meningkat dan dengan adanya peningkatan Kinerja Pegawai yang dilakukan maka sebagai timbal balik, organisasi sepatutnya memberikan imbalan atau pemberian penghargaan yang setimpal dengan kinerja yang diberikan. Hal ini akan meningkatkan Kinerja Pegawai yang dilakukan. Sehingga dengan demikian Kinerja Pegawai akan dipengaruhi oleh berapa besar kepemimpinan yang diberikan oleh organisasi. Organisasilah yang harus berperan aktif dalam menjaga Kinerja Pegawai melalui Kepemimpinan. Organisasi harus menjaga agar Kepemimpinan tetap ada di dalam program organisasi dan salah satunya adalah dengan adanya inovasi pelatihan yang diberikan.

Pelatihan dalam organisasi dapat mempengaruhi hasil kerja dan pencapaian tujuan komunikasi dan hubungan yang terjadi dalam suatu instansi berkaitan dengan kinerja pegawai. Komunikasi yang efektif dapat mencapai saling pengertian antara individu atau kelompok sehingga terbentuk kondisi sosial yang dapat memotivasi untuk meningkatkan produktivitas. Hasil pelatihan diharapkan karyawan secara lebih giat melaksanakan tugas-tugasnya, sehingga pekerjaan akan dapat diselesaikan lebih cepat dan lebih baik.

Pada dasarnya hasil penelitian ini menunjukkan bahwa kepemimpinan di Kelurahan Sidodadi masih perlu ditingkatkan yang ditunjukkan oleh kedisiplinan dalam menjalankan tugas sesuai dengan wewenangnya, mentaati tata tertib yang ada, 
menggunakan peralatan organisasi sesuai dengan prosedur yang benar serta ditunjukkan dari pelaksanaan kepemimpinan yang mendorong terhadap peningkatan kinerja pegawai meskipun belum terlaksana secara maksimal.

\section{SIMPULAN DAN SARAN SIMPULAN}

Berdasarkan hasil pengolahan data data secara statistik dan pembahasan hasil pengolahan, maka variabel Kepemimpinan berpengaruh secara signifikan dalam meningkatkan Kinerja Pegawai. Artinya, pelatihan sangat dominan untuk Kinerja Pegawai dengan berbagai teknik, pengembangan serta inovasi dalam pelaksanaan Kepemimpinan terutama bagi pegawai maupun bagi para instruktur sehingga akan tetap mampu mengikuti perkembangan serta kemajuan teknis Kepemimpinan yang adaptif dengan perkembangan serta kebutuhan lingkungan.

Pengaruh secara parsial, bahwa variabel Kepemimpinan melaui dimensidimensinya berpegaruh signifikan terhadap Kinerja Pegawai, yaitu melalui Legitimate Power (kekuasaan formal) dan Personal Power (Kemampuan Diri)

Pengaruh lain (epsilon) terhadap Kinerja Pegawai, tidak hanya dipengaruhi oleh variabel Kepemimpinan semata, akan tetapi berdasarkan prediksi peneliti terdapat pengaruh lain seperti pengawasan, metode, kreativitas, dan variabel lainnya yang perlu diteliti lebih lanjut dalam pengembangan teroi dan konsep lebih lanjut.

\section{SARAN}

Berdasarkan simpulan penelitian ini beberapa saran kiranya dapat menjadi masukan bagi peningkatan kinerja pegwai di kantor Kelurahan Sidodadi Kecamatan Wonomulyo Kabupaten Polewali Mandar sebagai berikut :

1. Sebelum mengimplementasikan kebijakan Kepemimpinan secara teknis, terlebih dahulu perlu dilakukan Analisis program Kepemimpinan dengan target maupun tujuan yang jelas meliputi: Ability (kemampuan), Skill (Keahlian), dan Pengetahuan yang dimiliki (Knoewledge) secara keseluruhan.

2. Dalam menyempurnakan program Kepemimpinan, program tentang peningkatan kemampuan, kompetensi serta skill, sebaiknya mengakomodir kebutuhan dalam upaya meningkatkan Kinerja Pegawai dan efektifnya Kepemimpinan.

3. Sebagai salah satu upaya peningkatan kinerja pegawai, penerapan pelatihan semstinya disesuaikan dengan beban kebutuhan, target, tujuan, sasaran, kualitas, kuantitas, ketepatan waktu dan ketepatan, kecepatan, akurasi, standar hasil Kepemimpinan.

\section{DAFTAR PUSTAKA}

A.Yukl, G. (2013). Leadership in Organizations. Perason.

Nurdin, N. H., Indonesia, U., \& Makassar, T. (2019). Jurnal Ilmiah Paranata Edu Volume 1 No 1 , Maret 2019 ISSN : 26566788 OPTIMALISASI PELAYANAN PUBLIK DALAM PERSPEKTIF NEW PUBLICK Jurnal Ilmiah Paranata Edu Volume 1 No 1, Maret 2019 ISSN : 26566788. 1(1), 1-13.

Puspita, A. (2016). Pengaruh lingkungan kerja, komunikasi dan kepemimpinan terhadap kinerja pegawai (.2(2).

Raven, B. H. (2014). The bases of social power. (January 1959).

Riset, J., \& Dan, A. (2014). Analisis pengaruh kepemimpinan dan budaya organisasi terhadap kinerja pegawai dengan sistem. 14, 77-97. 
Volume 2 No. 1, Mei 2020

Rorimpandey, L. (n.d.). GAYA KEPEMIMPINAN TRANSFORMASIONAL, TRANSAKSIONAL, SITUASIONAL, PELAYANAN DAN AUTENTIK TERHADAP KINERJA PEGAWAI KELURAHAN DI KECAMATAN BUNAKEN KOTA MANADO. 1(4), 22332244. 